\title{
Synthesis and structure of copper(II) complexes: Potential cyanide sensor and oxidase model
}

\author{
PALASH MONDAL, SANKAR PRASAD PARUA, POULAMI PATTANAYAK, UTTAM DAS \\ and SURAJIT CHATTOPADHYAY* \\ Department of Chemistry, University of Kalyani, Kalyani 741 235, India \\ e-mail: scha8@ rediffmail.com
}

MS received 9 October 2015; revised 5 January 2016; accepted 17 February 2016

\begin{abstract}
The new complexes of compositions $\left[\left(\mathrm{L}_{\mathrm{a}}\right)_{2} \mathrm{Cu}\right]$ and $\left[\left(\mathrm{L}_{\mathrm{b}}\right)_{2} \mathrm{Cu}\right]$ were prepared by treating with 2-hydroxy-5-methyl-3-(2-aryldiazenyl)phenylimino) methyl) benzaldehyde $\left(\mathrm{HL}_{\mathrm{a}}\right)$ and ethyl-2-cyano-3-(2hydroxy-5-methyl-3-(-(2-aryldiazenyl) phenylimino) methyl) phenyl) acrylate $\left(\mathrm{HL}_{\mathrm{b}}\right)$ ligands [where aryl is phenyl for $\mathrm{HL}_{\mathrm{a}}^{1}$ and $\mathrm{HL}_{\mathrm{b}}{ }^{1} ; p$-methyl phenyl for $\mathrm{HL}_{\mathrm{a}}{ }^{2}$ and $\mathrm{HL}_{\mathrm{b}}{ }_{\mathrm{b}}^{2}$; and $p$-chloro phenyl for $\mathrm{HL}_{\mathrm{a}}{ }^{3}$ and $\mathrm{HL}_{\mathrm{b}}{ }^{3}$ ] with $\mathrm{Cu}(\mathrm{OAc})_{2} \cdot \mathrm{H}_{2} \mathrm{O}$, respectively. Both the bis copper(II) complexes consist of tridentate $(\mathrm{N}, \mathrm{N}, \mathrm{O})$ anionic ligands, $\mathrm{L}_{\mathrm{a}}^{-}$or $\mathrm{L}_{\mathrm{b}}{ }^{-}$. X-ray structures of the representative complexes $\left[\left(\mathrm{L}_{\mathrm{a}}^{1}\right)_{2} \mathrm{Cu}\right]$ and $\left[\left(\mathrm{L}_{\mathrm{b}}{ }^{2}\right)_{2} \mathrm{Cu}\right]$ were determined to confirm the molecular species unequivocally. The molecular structure of copper complexes exhibited tetragonally distorted (Jahn-Teller) geometry consistent with the $\mathrm{d}^{9}$ configuration of $\mathrm{Cu}$ (II) metal ion. Oxidation of benzyl alcohols using the newly synthesized complexes as catalyst has been studied. Photoluminescence properties of $\left[\left(\mathrm{L}_{\mathrm{a}}^{2}\right)_{2} \mathrm{Cu}\right]$ and $\left[\left(\mathrm{L}_{\mathrm{b}}{ }^{2}\right)_{2} \mathrm{Cu}\right]$ were exploited for selective cyanide recognition. The $\left[\left(\mathrm{L}_{\mathrm{b}}\right)_{2} \mathrm{Cu}\right]$, complexes displayed antibacterial activity toward gram positive and gram negative bacteria.
\end{abstract}

Keywords. 2-hydroxy-5-methyl-3-(2-aryldiazenyl)phenylimino) methyl) benzaldehyde; ethyl-2-cyano-3-(2hydroxy-5-methyl-3-(-(2-aryldiazenyl)phenylimino) methyl) phenyl) acrylate, X-ray structure; tridentate $(\mathrm{N}, \mathrm{N}, \mathrm{O})$; photoluminescence.

\section{Introduction}

The chemistry of transition metal complexes incorporating azo ligands have been explored considerably during the last few decades. ${ }^{1-19}$ Several chemical properties of copper complexes have been attributed to easy accessibility to $\mathrm{Cu}$ (I), $\mathrm{Cu}$ (II) and $\mathrm{Cu}$ (III) oxidation states. ${ }^{3,20-38}$ Although a few studies on the coordination chemistry of copper using several kinds azo ligands have been reported ${ }^{3,39-45}$ but azo ligands have never been used for the synthesis of copper complexes targeting the oxidase models. The necessity to make progress in developing copper oxidase models requires synthesis of appropriate copper complexes to rationalize the functions of such oxidases unequivocally. ${ }^{46-52}$ Therefore, to study the coordination chemistry of $\mathrm{Cu}$ (II) incorporating the new azo ligands, ${ }^{53} \mathrm{HL}_{\mathrm{a}}$ and $\mathrm{HL}_{\mathrm{b}}$, with the fidelity of oxidase models, is expected to be interesting.

*For correspondence<smiles>[R]c1ccc(N=Nc2ccccc2N=Cc2cc(C)cc(C=O)c2O)cc1</smiles><smiles>[R]c1ccc(/N=N/c2ccccc2/N=C/c2cc(C)cc(/C=C(\C#N)C(=O)OCC)c2O)cc1</smiles>

Structures of $\mathrm{HL}_{\mathrm{a}}$ and $\mathrm{HL}_{\mathrm{b}}$

In addition, the chemistry of copper complexes incorporating azo-salen ligands, such as $\mathrm{HL}_{\mathrm{a}}$ and $\mathrm{HL}_{\mathrm{b}}$, is hitherto unknown. Amongst the natural copper containing metalloenzymes having oxidase activity, the notable examples are tyrosinase or galactose oxidase (GO) that are involved in physiological oxygenation or the electronic oxidations of substrates respectively. ${ }^{54-57}$ One of the functions played by GO is the oxidation of $1^{\circ}$ - alcohols to produce aldehydes in homogenous media under aerobic condition where dioxygen is the oxidant. ${ }^{54,55,58}$ 
The copper complexes under $\mathrm{N}_{2} \mathrm{O}_{2}$ coordination sphere where the ligands had ortho or para alkyl sulfanyl substituent as spectator, in terms of coordination to the metal centre, and both the O-donors were phenolato oxygen and both the N-donors were aldimino-N had exhibited GO activity. ${ }^{59}$ Encouraged by these, $\mathrm{HL}_{\mathrm{a}}$ and $\mathrm{HL}_{\mathrm{b}}$, were expected to be a potential ligands for the synthesis of copper complexes having catalytic property to oxidize primary alcohol to aldehyde since they are potential N,O donor ligands having substituents at the ortho position with respect to phenolic group.

Recently, we have shown that the Ni(II) complexes of $\mathrm{HL}_{\mathrm{a}}$ and $\mathrm{HL}_{\mathrm{b}}$ ligands can be the utilized for the selective recognition of cyanide ion. ${ }^{53}$ Therefore, we were also motivated to assess the emission properties of new copper complexes for screening the cyanide recognition property.

Herein, the synthesis and structure of a new family of $\mathrm{Cu}$ (II) complexes incorporating $\mathrm{HL}_{\mathrm{a}}$ and $\mathrm{HL}_{\mathrm{b}}$ ligands have been described. The new copper complexes, $\left[\left(\mathrm{L}_{\mathrm{a}}^{2}\right)_{2} \mathrm{Cu}\right]$ and $\left[\left(\mathrm{L}_{\mathrm{b}}^{2}\right)_{2} \mathrm{Cu}\right]$, have been screened to examine the catalytic activity toward oxidation of benzyl alcohols, cyanide recognition property and antibacterial activity of $\left[\left(\mathrm{L}_{\mathrm{b}}{ }^{2}\right)_{2} \mathrm{Cu}\right]$ against gram positive and gram negative bacteria.

\section{Experimental}

\subsection{Materials and methods}

The solvents used for all the reactions were of reagent grade (E.Merck, India) and were purified and dried by reported procedure. ${ }^{60}$ 2-(Arylazo) anilines were prepared according to the reported procedure. ${ }^{61}$ Copper acetate monohydrate was purchased from Sisco Research Laboratories (SRL), India. The ligands were prepared following the reported procedure. ${ }^{53}$ Microanalysis $(\mathrm{C}, \mathrm{H}, \mathrm{N})$ was performed using a Perkin-Elmer $2400 \mathrm{C}, \mathrm{H}, \mathrm{N}, \mathrm{S} / \mathrm{O}$ series II elemental analyzer. Infrared spectra were recorded on a Parkin-Elmer L12000A FT-IR spectrometer with the samples prepared as $\mathrm{KBr}$ pellets. Electronic spectra were recorded on a Shimadzu UV- 1800 PC spectrophotometer.

\subsection{Syntheses of $\left[\left(L_{a}\right)_{2} \mathrm{Cu}\right]$ complexes}

The complexes $\left[\left(\mathrm{L}_{\mathrm{a}}^{1}\right)_{2} \mathrm{Cu}\right],\left[\left(\mathrm{L}_{\mathrm{a}}^{2}\right)_{2} \mathrm{Cu}\right]$, and $\left[\left(\mathrm{L}_{\mathrm{a}}^{3}\right)_{2} \mathrm{Cu}\right]$, were prepared by similar procedure a representative example for $\left[\left(\mathrm{L}_{\mathrm{a}}^{1}\right)_{2} \mathrm{Cu}\right]$, given below.

2.2a $\left[\left(L_{a}^{1}\right)_{2} \mathrm{Cu}\right]$ : To a methanolic solution of copper acetate $(0.058 \mathrm{~g}, 0.29 \mathrm{mmol})$, the ligand $\mathrm{HL}_{\mathrm{a}}{ }^{1}(0.002 \mathrm{~g}$, $0.58 \mathrm{mmol}$ ) was added and the mixture was then stirred for $3 \mathrm{~h}$. Brownish precipitate was obtained. The precipitate was dissolved in dichloromethane to form deep brown color and layered with hexane. After evaporating the solvent, fine crystals were obtained. The yield was $180 \mathrm{mg}(40 \%)$. Anal. Calc. (\%) for $\mathrm{C}_{42} \mathrm{H}_{32} \mathrm{CuN}_{6} \mathrm{O}_{4}$ (748): C 67.42, H 4.28, N 11.23. Found (\%): C 67.35, $\mathrm{H}$ 4.35, N 11.30. UV/Vis spectrum $\left(\mathrm{CH}_{2} \mathrm{Cl}_{2}\right) \lambda_{\max }(\epsilon$, $\left.\mathrm{M}^{-1} \mathrm{~cm}^{-1}\right)$ : 432 (7681), 291 (65201), 236 (29430). IR $\left(\mathrm{KBr}, \mathrm{cm}^{-1}\right): v=1619 \mathrm{~s}, 1446 \mathrm{~s}, 1665 \mathrm{~s}$.

$2.2 \mathrm{~b} \quad\left[\left(\mathrm{~L}_{a}^{2}\right)_{2} \mathrm{Cu}\right]$ and $\left[\left(\mathrm{L}_{a}^{3}\right)_{2} \mathrm{Cu}\right]$ : The $\left[\left(\mathrm{L}_{\mathrm{a}}^{2}\right)_{2} \mathrm{Cu}\right]$ and $\left[\left(\mathrm{L}_{\mathrm{a}}^{3}\right)_{2} \mathrm{Cu}\right]$ complexes were prepared following similar procedure as described for $\left[\left(\mathrm{L}_{\mathrm{a}}^{1}\right)_{2} \mathrm{Cu}\right]$ using $\mathrm{HL}_{\mathrm{a}}^{2}$ and $\mathrm{HL}_{\mathrm{a}}^{3}$ in place of $\mathrm{HL}_{\mathrm{a}}^{1}$ ligand. Yield: $0.185 \mathrm{~g}(42 \%)$ and $0.175 \mathrm{~g}$ (40\%), respectively. Anal. Calc. (\%) for $\mathrm{C}_{44} \mathrm{H}_{36} \mathrm{CuN}_{6} \mathrm{O}_{4}$ (776): $\mathrm{C}$ 68.07, $\mathrm{H} 4.67, \mathrm{~N}$ 10.13. Found (\%): C 68.10, H 4.62, N 10.15. UV/Vis spectrum $\left(\mathrm{CH}_{2} \mathrm{Cl}_{2}\right) \lambda_{\max }\left(\epsilon, \mathrm{M}^{-1} \mathrm{~cm}^{-1}\right): 433$ (9376), 310 (39075), 235 (42535). IR (KBr pellets, $\left.\mathrm{cm}^{-1}\right): v=1618 \mathrm{~s}, 1446 \mathrm{~s}$, 1664 s. Anal. Calcd. (\%) $\mathrm{C}_{42} \mathrm{H}_{30} \mathrm{CuN}_{6} \mathrm{O}_{4} \mathrm{Cl}_{2}$ (817): $\mathrm{C}$ 61.72, H 3.67, N 10.28. Found (\%): C 61.85, H 3.45, N 10.50. UV/Vis spectrum $\left(\mathrm{CH}_{2} \mathrm{Cl}_{2}\right) \lambda_{\max }\left(\epsilon, \mathrm{M}^{-1} \mathrm{~cm}^{-1}\right)$ : 435 (9406), 312 (39086), 238 (42555). IR $\left(\mathrm{KBr}, \mathrm{cm}^{-1}\right)$ : $v=1619 \mathrm{~s}, 1436 \mathrm{~s}, 1671 \mathrm{~s}$.

\subsection{Syntheses of $\left[\left(L_{b}\right)_{2} \mathrm{Cu}\right]$ complexes}

The complexes, $\left[\left(\mathrm{L}_{\mathrm{b}}^{1}\right)_{2} \mathrm{Cu}\right],\left[\left(\mathrm{L}_{\mathrm{b}}{ }^{2}\right)_{2} \mathrm{Cu}\right]$, and $\left[\left(\mathrm{L}_{\mathrm{b}}{ }^{3}\right)_{2} \mathrm{Cu}\right]$, were prepared by similar procedure used for the representative example $\left[\left(\mathrm{L}_{\mathrm{b}}{ }^{1}\right)_{2} \mathrm{Cu}\right]$, described below.

2.3a $\left[\left(L_{b}^{l}\right)_{2} \mathrm{Cu}\right]$ : A $5 \mathrm{~mL}$ methanolic solution of $\mathrm{Cu}(\mathrm{OAc})_{2} . \mathrm{H}_{2} \mathrm{O}(0.045 \mathrm{~g}, 0.23 \mathrm{mmol}), 10 \mathrm{~mL}$ methanol solution of $\mathrm{HL}_{\mathrm{b}}{ }^{1}(0.002 \mathrm{mg}, 0.456 \mathrm{mmol})$ was added and the mixture was stirred for $2 \mathrm{~h}$. Dark brown product was precipitated which was collected by filtration and was washed with petroleum ether and hexane. The precipitate was then recrystallized from a dichloromethanehexane solvent mixture. Yield: $0.180 \mathrm{~g}(42 \%)$. Anal. calc. (\%) for $\mathrm{C}_{52} \mathrm{H}_{42} \mathrm{CuN}_{8} \mathrm{O}_{6}$ (938): C, 66.55; H, 4.51; $\mathrm{N}, 11.94$. Found (\%): C, 66.52; H, 4.54; N, 11.90. UV/Vis spectrum $\left(\mathrm{CH}_{2} \mathrm{Cl}_{2}\right) \lambda_{\max }\left(\epsilon, \mathrm{M}^{-1} \mathrm{~cm}^{-1}\right): 475$ (5740), 293 (16380), 230 (15800), IR ( $\left.\mathrm{KBr}, \mathrm{cm}^{-1}\right)$ : $v=1616 \mathrm{~s}, 1476 \mathrm{~s}, 1692 \mathrm{~s}, 2220 \mathrm{~s}$.

$2.3 \mathrm{~b} \quad\left[\left(L_{b}^{2}\right)_{2} \mathrm{Cu}\right]$, and $\left[\left(\mathrm{L}_{b}^{3}\right)_{2} \mathrm{Cu}\right]$ : Complexes $\left[\left(\mathrm{L}_{\mathrm{b}}^{2}\right)_{2}\right.$ $\mathrm{Cu}]$, and $\left[\left(\mathrm{L}_{\mathrm{b}}{ }^{3}\right)_{2} \mathrm{Cu}\right]$ were synthesized following the same procedure as for complex $\left[\left(\mathrm{L}_{\mathrm{b}}{ }^{1}\right)_{2} \mathrm{Cu}\right]$ using $\mathrm{HL}_{\mathrm{b}}{ }^{2}$ and $\mathrm{HL}_{\mathrm{b}}^{3}$ in place of $\mathrm{HL}_{\mathrm{b}}{ }^{1}$ respectively. Yield: $0.210 \mathrm{~g}$ (50\%) and Yield: $0.215 \mathrm{~g}(51 \%)$, respectively. Anal. calc. (\%) for $\mathrm{C}_{54} \mathrm{H}_{46} \mathrm{CuN}_{8} \mathrm{O}_{6}$ (967): C, 67.10; H, 4.80; $\mathrm{N}, 11.59$. Found (\%): C, 67.12; H, 4.76; N, 11.55 . UV/Vis spectrum $\left(\mathrm{CH}_{2} \mathrm{Cl}_{2}\right) \lambda_{\max }\left(\epsilon, \mathrm{M}^{-1} \mathrm{~cm}^{-1}\right): 474$ 
(5270), 296 (16850), 238 (11240), IR $\left(\mathrm{KBr}, \mathrm{cm}^{-1}\right): v=$ $1617 s, 1475 s, 1674 s, 2219 s$.

Anal. calc. (\%) for $\mathrm{C}_{52} \mathrm{H}_{40} \mathrm{Cl}_{2} \mathrm{CuN}_{8} \mathrm{O}_{6}$ (1005): C, 62.00; H, 4.00; N, 11.12. Found (\%): C, 61.98; $\mathrm{H}, 3.95 ; \mathrm{N}, 11.15$. UV/Vis spectrum $\left(\mathrm{CH}_{2} \mathrm{Cl}_{2}\right) \lambda_{\max }$ ( $\left.\epsilon, \mathrm{M}^{-1} \mathrm{~cm}^{-1}\right)$ : 476 (5330), 309 (18700), 240 (10400), IR $\left(\mathrm{KBr}, \mathrm{cm}^{-1}\right): v=1616 s, 1474 s, 1703 s, 2220 s$.

\section{$2.4 \mathrm{X}$-ray structure determination of $\left[\left(\mathrm{L}_{a}^{1}\right)_{2} \mathrm{Cu}\right]$ and [( $\left.\left.L_{b}^{2}\right)_{2} \mathrm{Cu}\right]$}

Single Crystals of $\left[\left(\mathrm{L}_{\mathrm{a}}^{1}\right)_{2} \mathrm{Cu}\right]$ and $\left[\left(\mathrm{L}_{\mathrm{b}}{ }^{2}\right)_{2} \mathrm{Cu}\right]$ were grown by slow diffusion of hexane in dichloromethane solution at $25^{\circ} \mathrm{C}$. Data were collected on a Bruker SMART CCD diffractometer using Mo-K $\alpha$ monochromator $(\lambda=0.71073)$. Structure solutions were performed using Shellx 97 PC version program. ${ }^{62}$ Full matrix least square refinements on F2 were performed using SHELXL-97 program. ${ }^{63}$ All the non-hydrogen atoms were refined anisotropically using full-matrix least squares method. Hydrogen atoms were included for structure factor calculations after placing them at calculated positions. Atomic coordinates and isotropic thermal parameters of $\left[\left(\mathrm{L}_{\mathrm{a}}^{1}\right)_{2} \mathrm{Cu}\right]$ and $\left[\left(\mathrm{L}_{\mathrm{b}}{ }^{2}\right)_{2} \mathrm{Cu}\right]$ are given in table 1 .

\subsection{Procedure for the catalytic oxidation of benzyl alcohol}

A mixture of benzyl alcohol $(0.5 \mathrm{mmol})$, catalyst $\left[\left(\mathrm{L}_{\mathrm{a}}^{2}\right)_{2} \mathrm{Cu}\right](4 \mathrm{~mol} \%)$ or $\left[\left(\mathrm{L}_{\mathrm{b}}^{2}\right)_{2} \mathrm{Cu}\right](4 \mathrm{~mol} \%)$ and $30 \%$ $\mathrm{H}_{2} \mathrm{O}_{2}$ (5 equiv.) was taken in $10 \mathrm{~mL}$ acetonitrile solvent in a round bottom flask. The mixture was vigorously stirred at $70^{\circ} \mathrm{C}$ for $1 \mathrm{~h}$. The reaction was monitored by TLC. After completion of the reaction, the solvent was removed, the organic phase was separated and dried over $\mathrm{Na}_{2} \mathrm{SO}_{4}$ and the product was purified by column chromatography (hexane/ethyl acetate). Yields were determined by weighing the isolated product, which was characterized by ${ }^{1} \mathrm{H}$ NMR and IR spectroscopy.

\subsection{General procedure for Photoluminescence studies}

Stock solutions of the complexes $\left(\left[\left(\mathrm{L}_{\mathrm{a}}^{2}\right)_{2} \mathrm{Cu}\right]\right.$ and $\left[\left(\mathrm{L}_{\mathrm{b}}^{2}\right)_{2} \mathrm{Cu}\right]$ ) were prepared in $\mathrm{CH}_{3} \mathrm{CN}$ (mixed with $0.1-0.2 \%$ DMSO) solvent in the concentration range $\sim 10^{-5} \mathrm{M}$. Stock solutions of tetra butyl ammonium anions $\left(\mathrm{F}^{-}, \mathrm{Cl}^{-}, \mathrm{Br}^{-}, \mathrm{I}^{-}, \mathrm{CN}^{-}, \mathrm{ClO}_{4}^{-}, \mathrm{OAc}^{-}, \mathrm{HSO}_{4}^{-}\right.$ and $\mathrm{H}_{2} \mathrm{PO}_{4}^{-}$) were prepared in the same solvent in the concentration range $\sim 10^{-3} \mathrm{M}$. For each measurement $2 \mathrm{~mL}$ solution was taken in the cuvette. Solutions of anions, in $\mu \mathrm{L}$, were added to these $2 \mathrm{~mL}$ solutions to study the effect of anion.

\subsection{Microbial activity}

The metal Complex $\left[\left(\mathrm{L}_{\mathrm{b}}^{2}\right)_{2} \mathrm{Cu}\right]$ and a reference commercial antibiotic (antibacterial drug) viz. Chloramphenicol were tested in vitro to assess their growth inhibitory activity against human pathogenic two Gram positive bacteria, viz. Bacillus subtilis (MTCC 441), Staphylococcus aureus (MTCC 2522) and three Gram negative bacteria viz. Pseudomonas aeruginosa (MTCC 741), Shigella dysenteriae (Clinical isolate) and Escherichia

Table 1. Crystallographic data for $\left[\left(\mathrm{L}_{\mathrm{a}}^{1}\right)_{2} \mathrm{Cu}\right]$ and $\left[\left(\mathrm{L}_{\mathrm{b}}^{2}\right)_{2} \mathrm{Cu}\right]$.

\begin{tabular}{lcc}
\hline Chemical formula & $\mathrm{C}_{42} \mathrm{H}_{32} \mathrm{CuN}_{6} \mathrm{O}_{4}$ & $\mathrm{C}_{54} \mathrm{H}_{46} \mathrm{CuN}_{8} \mathrm{O}_{6}$ \\
Formula weight & 748.29 & 1006.56 \\
Crystal system & Triclinic & monoclinic \\
space group & $\mathrm{P}-1(\mathrm{No} .2)$ & $\mathrm{C} 2 / \mathrm{c}$ (No. 15) \\
$a / \AA$ & $7.4448(5)$ & $19.934(4)$ \\
$b / \AA$ & $10.1717(7)$ & $15.387(3)$ \\
$c / \AA$ & $12.8503(8)$ & $15.768(3)$ \\
$\alpha / \mathrm{deg}$ & $97.7210(10)$ & 90 \\
$\beta / \mathrm{deg}$ & $106.8260(10)$ & $97.961(4)$ \\
$\gamma / \mathrm{deg}$ & $109.9320(10)$ & 90 \\
$\lambda / \AA$ & 0.71073 & 0.71073 \\
$V / \AA$ & $8789.8(16)$ \\
$\mathrm{F}(000)$ & $845.78(10)$ & 2092 \\
$Z$ & 387 & 4 \\
$T / \mathrm{K}$ & 1 & 293 \\
$D / \mathrm{mg} / \mathrm{m}^{-3}$ & 293 & 1.396 \\
$\mu / \mathrm{mm}{ }^{-1}$ & 1.469 & 0.521 \\
$\mathrm{R} 1($ all data) & 0.701 & 0.0609 \\
wR2[I $>2 \sigma(I)]$ & 0.0330 & 0.1959 \\
$\mathrm{GOF}$ & 0.0936 & 0.98 \\
\hline
\end{tabular}


coli (MTCC 443). All the bacterial strains except Shigella dysenteriae were obtained from the Institute of Microbial Technology, Chandigarh, India. The antibacterial tests were carried out by disc diffusion method $^{64}$ using $100 \mu \mathrm{L}$ of the suspension containing $10^{8} \mathrm{CFU} / \mathrm{mL}$ of bacteria (turbidity of 0.5 MacFarland standards) on nutrient agar. The discs $(6 \mathrm{~mm}$ in diameter) were impregnated with $60 \mu \mathrm{g} / \mathrm{disc}$ placed on the inoculated agar. Negative controls were prepared using $100 \%$ DMSO. Chloramphenicol (10 $\mu \mathrm{g}$ per disc) was used as positive reference standard to determine the sensitivity of each bacterial species tested. The inoculated plates were incubated at $37^{\circ} \mathrm{C}$ for $24 \mathrm{~h}$. The antibacterial activity was evaluated by measuring the zone of inhibition, the diameters of these zones being measured in millimeters against the test organisms.

The minimal inhibitory concentration (MIC) values were followed with the bacteria strains sensitive to the metal complex in the disc diffusion assay. The MIC was defined as the lowest concentration of the compound to inhibit the growth of microorganisms. The metal complex was dissolved in $10 \%$ DMSO, first diluted to the highest concentration $(1000 \mu \mathrm{g} / \mathrm{mL})$ to be tested, and then serial twofold dilutions were made in order to obtain a concentration range from 3.9 to $1000 \mu \mathrm{g} / \mathrm{mL}$ in $10 \mathrm{~mL}$ sterile test tubes containing the nutrient broth. MIC values of the metal complex against bacterial strains were determined based on the micro well dilution method as previously described ${ }^{65}$ Each plate was covered with a sterile plate sealer and then incubated at the appropriate temperature $37^{\circ} \mathrm{C}$ for $24 \mathrm{~h}$. The bacterial growth was determined by absorbance measured at $600 \mathrm{~nm}$ using the ELx 800 universal microplate reader (Biotek Instrument Inc., Winooski, USA).

\section{Results and Discussion}

\subsection{Syntheses}

The reactions of the new $\mathrm{HL}_{\mathrm{a}}$ and $\mathrm{HL}_{\mathrm{b}}$ ligands with $\mathrm{Cu}(\mathrm{OAc})_{2} \cdot \mathrm{H}_{2} \mathrm{O}$ in methanol afforded brown complexes of compositions $\left[\left(\mathrm{L}_{\mathrm{a}}\right)_{2} \mathrm{Cu}\right]$ and $\left[\left(\mathrm{L}_{\mathrm{b}}\right)_{2} \mathrm{Cu}\right]$, respectively (scheme 1). Both the complexes were paramagnetic matching with one unpaired electron as expected for $\mathrm{Cu}$ (II) metal ions. The suitable crystals of $\left[\left(\mathrm{L}_{\mathrm{a}}^{1}\right)_{2} \mathrm{Cu}\right]$ and $\left[\left(\mathrm{L}_{\mathrm{b}}{ }^{2}\right)_{2} \mathrm{Cu}\right]$ complexes for $\mathrm{x}$-ray studies were grown from dichloromethane-hexane solvent mixture.

\subsection{Characterization}

The electronic spectra of $\left[\left(\mathrm{L}_{\mathrm{a}}\right)_{2} \mathrm{Cu}\right]$ and $\left[\left(\mathrm{L}_{\mathrm{b}}\right)_{2} \mathrm{Cu}\right]$ are distinctly different from the ligand $\mathrm{HL}_{\mathrm{a}}$ and $\mathrm{HL}_{\mathrm{b}}$ where the lowest energy absorption appeared near $432 \mathrm{~nm}$ and $475 \mathrm{~nm}$, respectively. ${ }^{53}$ Representative UV-Vis spectra of $\mathrm{HL}_{\mathrm{a}}{ }^{1}, \mathrm{HL}_{\mathrm{b}}{ }^{2},\left[\left(\mathrm{~L}_{\mathrm{a}}{ }^{1}\right)_{2} \mathrm{Cu}\right]$ and $\left[\left(\mathrm{L}_{\mathrm{b}}{ }^{2}\right)_{2} \mathrm{Cu}\right]$ are shown in figure 1. Spectral data are given in the Experimental section.

The $v_{\mathrm{C}=\mathrm{N}}$ of $\left[\left(\mathrm{L}_{\mathrm{a}}\right)_{2} \mathrm{Cu}\right]$ complexes appear in the lower range $\left(1618-1620 \mathrm{~cm}^{-1}\right)$ compared to the ligand signifying the coordination to the metal centre. The $v_{\mathrm{N}=\mathrm{N}}$ band of the ligand $\left(\sim 1468 \mathrm{~cm}^{-1}\right)$ shifts to lower frequency after formation of the $\left[\left(\mathrm{L}_{\mathrm{a}}\right)_{2} \mathrm{Cu}\right] \mathrm{com}$ plex $\left(1446 \mathrm{~cm}^{-1}\right)$, consistent with coordination with azo nitrogen. The UV-Vis spectra of $\left[\left(\mathrm{L}_{\mathrm{a}}\right)_{2} \mathrm{Cu}\right]$ and $\left[\left(\mathrm{L}_{\mathrm{b}}\right)_{2} \mathrm{Cu}\right]$ are given in Supplementary Information (figures $\mathrm{S} 1-\mathrm{S} 6$ ).

The characteristic stretching frequencies of the $v_{\mathrm{C}=\mathrm{N}}$ in $\left[\left(\mathrm{L}_{\mathrm{b}}\right)_{2} \mathrm{Cu}\right]$ shifted to lower values at $1616 \mathrm{~cm}^{-1} \mathrm{com}-$ pared to the ligand $\left(\sim 1620 \mathrm{~cm}^{-1}\right)$ due to coordination

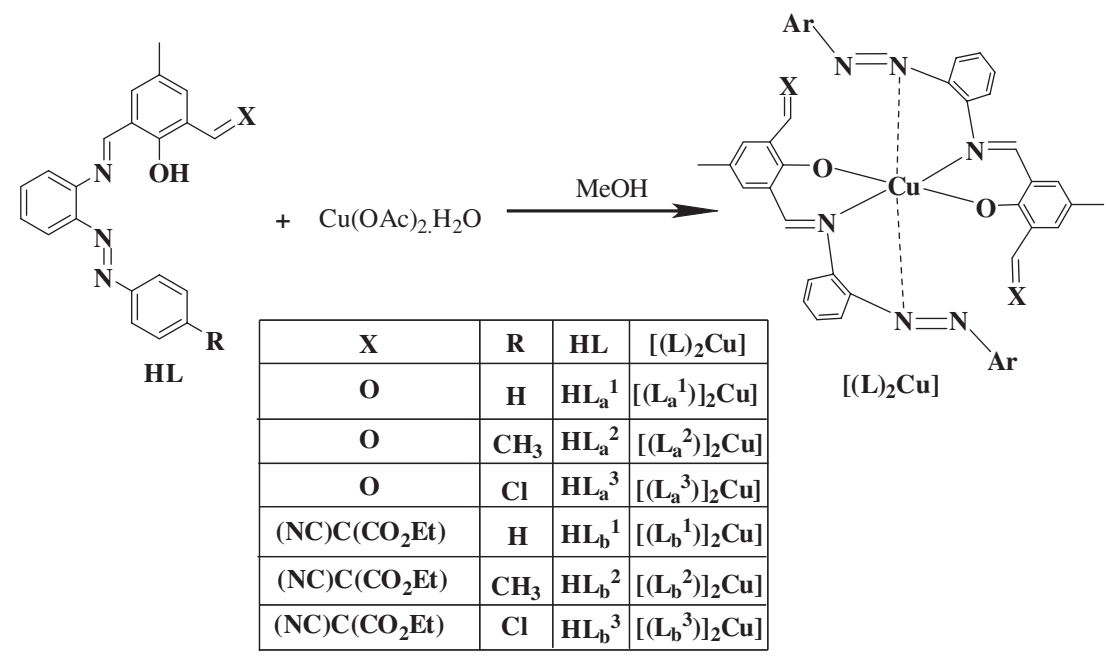

Scheme 1. Preparation and structure of Complexes. 
to the metal centre. The $v_{\mathrm{N}=\mathrm{N}}$ of complex $\left[\left(\mathrm{L}_{\mathrm{b}}\right)_{2} \mathrm{Cu}\right]$ was shifted at $1476 \mathrm{~cm}^{-1}$ with respect to ligand $\left(\sim 1480 \mathrm{~cm}^{-1}\right)$ indicating coordination of azo nitrogen. The relevant IR data are collected in experimental section. The IR spectra of $\left[\left(\mathrm{L}_{\mathrm{a}}\right)_{2} \mathrm{Cu}\right]$ and $\left[\left(\mathrm{L}_{\mathrm{b}}\right)_{2} \mathrm{Cu}\right]$ are given in Supplementary Information (figures S7-S12).

\section{$3.3 X$-ray structure of $\left[\left(L_{a}^{1}\right)_{2} \mathrm{Cu}\right]$ and $\left[\left(L_{b}^{2}\right)_{2} \mathrm{Cu}\right]$}

Suitable crystals of $\left[\left(\mathrm{L}_{\mathrm{a}}^{1}\right)_{2} \mathrm{Cu}\right]$ and $\left[\left(\mathrm{L}_{\mathrm{b}}^{2}\right)_{2} \mathrm{Cu}\right]$ were grown by slow diffusion of hexane into dichloromethane solution. The X-ray structure of $\left[\left(\mathrm{L}_{\mathrm{a}}^{1}\right)_{2} \mathrm{Cu}\right]$ and $\left[\left(\mathrm{L}_{\mathrm{b}}^{2}\right)_{2} \mathrm{Cu}\right]$ were determined and described below.

The perspective views of $\left[\left(\mathrm{L}_{\mathrm{a}}^{1}\right)_{2} \mathrm{Cu}\right]$ and $\left[\left(\mathrm{L}_{\mathrm{b}}{ }^{2}\right)_{2} \mathrm{Cu}\right]$ complexes are shown in figures $2 \mathrm{a}$ and $2 \mathrm{~b}$. Selected bond parameters of $\left[\left(\mathrm{L}_{\mathrm{a}}^{1}\right)_{2} \mathrm{Cu}\right]$ and $\left[\left(\mathrm{L}_{\mathrm{b}}{ }^{2}\right)_{2} \mathrm{Cu}\right]$ complexes are listed in table 2 and table 3 , respectively.

In each complex, the $\mathrm{Cu}$ centre is coordinated by two phenolato oxygens $\left(\mathrm{O} 1\right.$ or $\left.\mathrm{O}_{\mathrm{ph}}\right)$, two azomethine

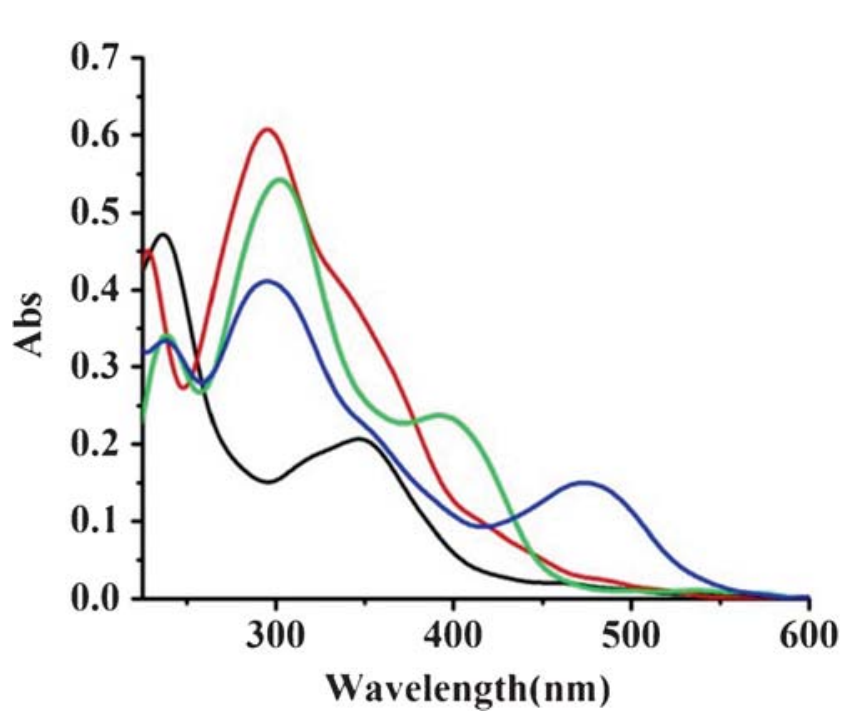

Figure 1. UV-Vis spectra of $\mathrm{HL}_{\mathrm{a}}{ }^{1}(-), \mathrm{HL}_{\mathrm{b}}^{2}(-)$, $\left[\left(\mathrm{L}_{\mathrm{a}}^{1}\right)_{2} \mathrm{Cu}\right](-)$ and $\left[\left(\mathrm{L}_{\mathrm{b}}^{2}\right)_{2} \mathrm{Cu}\right](-)$.

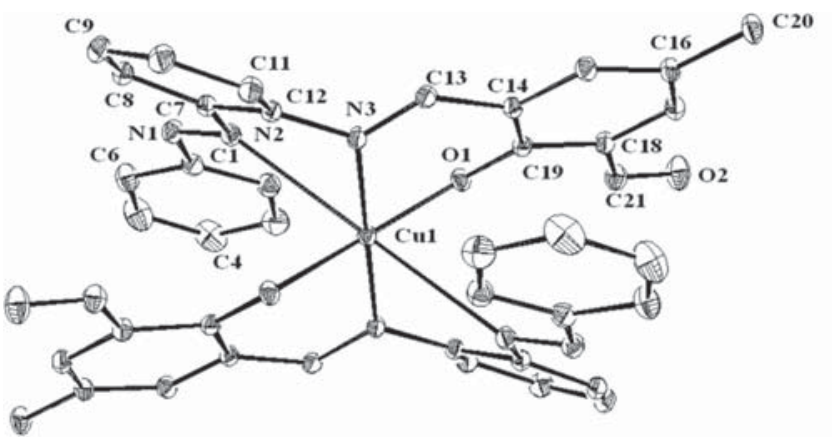

(a) nitrogen ( $\mathrm{N} 3$ or $\mathrm{N}_{\mathrm{im}}$ ) and two distal azo nitrogen ( $\mathrm{N} 2$ or $\mathrm{N}_{\mathrm{azo}}$ ) signifying the tetragonally distorted octahedral geometry around copper(II) consistent with the JahnTeller distortion in $\mathrm{d}^{9}$ ion. ${ }^{66-68}$ The elongated bond distances are given in structure $\mathbf{I}$ below. The asymmetric unit of both the complexes consist of half molecule where $\mathrm{Cu}$ (II) occupies the special position. Considering tridentate mode of coordination of the deprotonated anionic ligands, $\left(\mathrm{L}_{\mathrm{a}}^{1}\right)^{-}$and $\left(\mathrm{L}_{\mathrm{b}}^{2}\right)^{-}$, are facially oriented forming bis complexes. Cu- $\mathrm{N}_{\mathrm{im}}(1.977(1) \AA$ for $\left[\left(\mathrm{L}_{\mathrm{a}}^{1}\right)_{2} \mathrm{Cu}\right]$ and 1.960 (3) $\AA$ for $\left.\left[\left(\mathrm{L}_{\mathrm{b}}{ }^{2}\right)_{2} \mathrm{Cu}\right]\right)$ and $\mathrm{Cu}-\mathrm{O}_{\mathrm{ph}}\left(1.921(2) \AA\right.$ f for $\left[\left(\mathrm{L}_{\mathrm{a}}^{1}\right)_{2} \mathrm{Cu}\right]$ and 1.938(4) $\AA$ 自 for $\left.\left[\left(\mathrm{L}_{\mathrm{b}}^{2}\right)_{2} \mathrm{Cu}\right]\right)$ distances are within the normal range. ${ }^{69,70}$ Although the disordered methanol solvent (Oxygen is in special position and disordered as well) for $\left[\left(\mathrm{L}_{\mathrm{b}}^{2}\right)_{2} \mathrm{Cu}\right]$ could not be refined satisfactorily but that did not cause much difficulty toward unequivocal characterization of the complex.

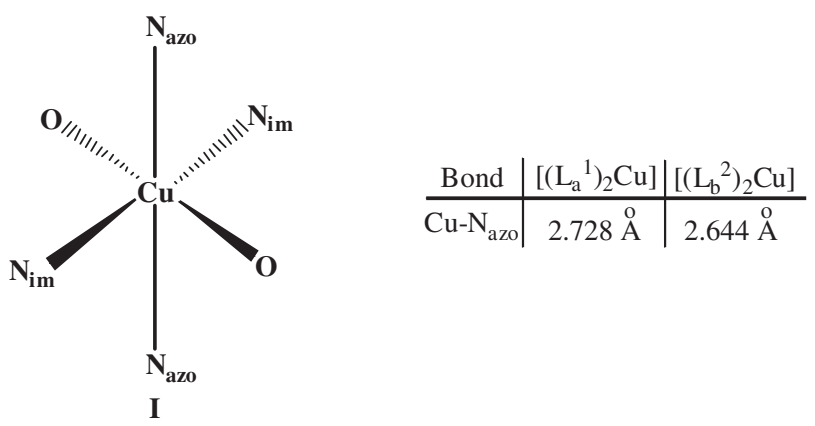

\section{Structure I}

\subsection{Selective oxidation of Benzyl alcohol}

One of the important activity of Galactose Oxidase (GO) involves the oxidation of alcohols to carbonyl compounds (aldehyde or ketones). ${ }^{59,71}$ Several $\mathrm{Cu}$ (II)

Figure 2. Perspective view of (a) $\left[\left(\mathrm{L}_{\mathrm{a}}^{1}\right)_{2} \mathrm{Cu}\right]$ and (b) $\left[\left(\mathrm{L}_{\mathrm{b}}^{2}\right)_{2} \mathrm{Cu}\right]$ with atom numbering scheme. The hydrogen atoms have been omitted for clarity. 
Table 2. Selected Bond Distances $(\AA)$ and Angles (deg) for Compound $\left[\left(\mathrm{L}_{\mathrm{a}}^{1}\right)_{2} \mathrm{Cu}\right]$.

\begin{tabular}{lccc}
\hline & & & \\
Cu1-N2 & Distances & N1-C1 & $1.420(2)$ \\
Cu1-N3 & $2.7277(15)$ & N2-C7 & $1.429(2)$ \\
Cu1-O1 & $1.9770(14)$ & N3-C12 & $1.423(2)$ \\
O1-C19 & $1.9212(10)$ & N3-C13 & $1.2883(19)$ \\
C1-C2 & $1.2991(17)$ & C14-C15 & $1.3988(19)$ \\
C1-C6 & $1.396(2)$ & C14-C19 & $1.431(2)$ \\
C2-C3 & $1.392(2)$ & C18-C19 & $1.423(2)$ \\
C5-C6 & $1.382(3)$ & C18-C21 & $1.466(2)$ \\
N1-N2 & $1.383(3)$ & O2-C21 & $1.215(2)$ \\
& $1.2516(19)$ & & \\
O1-Cu1-N2 & & Angles & \\
O1-Cu1-N3 & $105.67(5)$ & N2-C7-C12 & $116.35(14)$ \\
N2-Cu1-N3 & $89.33(5)$ & C13-C14-C19 & $121.45(12)$ \\
Cu1-O1-C19 & $67.99(5)$ & O1-C19-C18 & $120.28(14)$ \\
Cu1-N2-N1 & $120.86(10)$ & O1-C19-C14 & $123.35(14)$ \\
Cu1-N2-C7 & $140.25(12)$ & N1-N2-C7 & $113.27(14)$ \\
N2-N1-C1 & $99.38(9)$ & C12-N3-C13 & $118.64(14)$ \\
Cu1-N3-C12 & $114.71(14)$ & N1-C1-C2 & $125.35(14)$ \\
Cu1-N3-C13 & $119.27(9)$ & N1-C1-C6 & $114.22(15)$ \\
N2-C7-C8 & $122.07(12)$ & C2-C1-C6 & $120.36(16)$ \\
& $123.79(14)$ & & \\
\hline
\end{tabular}

Table 3. Selected Bond Distances $(\AA)$ and Angles (deg) for Compound $\left[\left(\mathrm{L}_{\mathrm{b}}{ }^{2}\right)_{2} \mathrm{Cu}\right]$.

\begin{tabular}{|c|c|c|c|}
\hline \multicolumn{4}{|c|}{ Distances } \\
\hline Cu1-N2 & 2.644(3) & N1-N2 & $1.253(4)$ \\
\hline Cu1-N3 & $1.960(3)$ & N3-C9 & $1.422(5)$ \\
\hline $\mathrm{Cu} 1-\mathrm{O} 1$ & $1.938(3)$ & N3-C14 & $1.289(5)$ \\
\hline $\mathrm{O} 1-\mathrm{C} 20$ & $1.307(4)$ & N4-C24 & $1.135(6)$ \\
\hline $\mathrm{O} 2-\mathrm{C} 25$ & $1.218(5)$ & C8-C9 & $1.398(5)$ \\
\hline $\mathrm{O} 3-\mathrm{C} 25$ & $1.335(5)$ & C14-C15 & $1.441(6)$ \\
\hline $\mathrm{O} 3-\mathrm{C} 26$ & $1.450(5)$ & $\mathrm{C} 15-\mathrm{C} 20$ & $1.438(5)$ \\
\hline $\mathrm{N} 2-\mathrm{C} 8$ & $1.443(5)$ & C19-C20 & $1.424(6)$ \\
\hline \multicolumn{4}{|c|}{ Angles } \\
\hline O1-Cu1-N2 & $102.41(11)$ & N2-C8-C9 & $115.2(4)$ \\
\hline O1-Cu1-N3 & $88.93(12)$ & $\mathrm{N} 2-\mathrm{C} 8-\mathrm{C} 13$ & $124.4(3)$ \\
\hline N2-Cu1-N3 & $69.16(11)$ & N3-C9-C8 & $117.7(3)$ \\
\hline Cu1-N2-N1 & $138.1(2)$ & N3-C9-C10 & $122.5(3)$ \\
\hline Cu1-N2-C8 & $99.6(2)$ & N3-C14-C15 & $123.3(4)$ \\
\hline Cu1-N3-C9 & $118.7(2)$ & C14-C15-C20 & $121.4(3)$ \\
\hline Cu1-N3-C14 & $121.3(3)$ & $\mathrm{O} 1-\mathrm{C} 20-\mathrm{C} 15$ & $122.3(4)$ \\
\hline $\mathrm{Cu} 1-\mathrm{O} 1-\mathrm{C} 20$ & $117.2(2)$ & O1-C20-C19 & $120.0(3)$ \\
\hline
\end{tabular}

complexes, mimicking the GO models, have been used as catalyst for the oxidation of $1^{\circ}$-alcohols to aldehyde. ${ }^{58,72}$ Selective oxidation of alcohols to the corresponding carbonyl compounds (aldehyde or ketones) is an important and widely used reaction in laboratory scale organic synthesis as well as in large scale in chemical industry. ${ }^{73-76}$ These background information prompted us to examine the oxidase activity of $\left[\left(\mathrm{L}_{\mathrm{a}}^{2}\right)_{2} \mathrm{Cu}\right]$ and $\left[\left(\mathrm{L}_{\mathrm{b}}^{2}\right)_{2} \mathrm{Cu}\right]$. Oxidation of benzyl alcohol to benzaldehyde by the oxidant $\mathrm{H}_{2} \mathrm{O}_{2}(30 \%)$ in the presence of catalytic amount of $\left[\left(\mathrm{L}_{\mathrm{a}}^{2}\right)_{2} \mathrm{Cu}\right]$ or $\left[\left(\mathrm{L}_{\mathrm{b}}^{2}\right)_{2} \mathrm{Cu}\right]$ complex have been studied Eq. (1). The optimization of the oxidation has been done by varying the relative

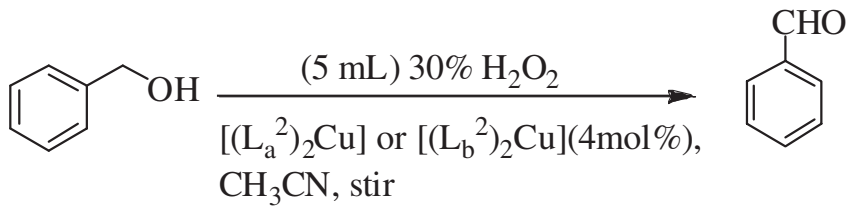

proportions of hydrogen peroxide with respect to the catalysts and also by varying the reaction time and 


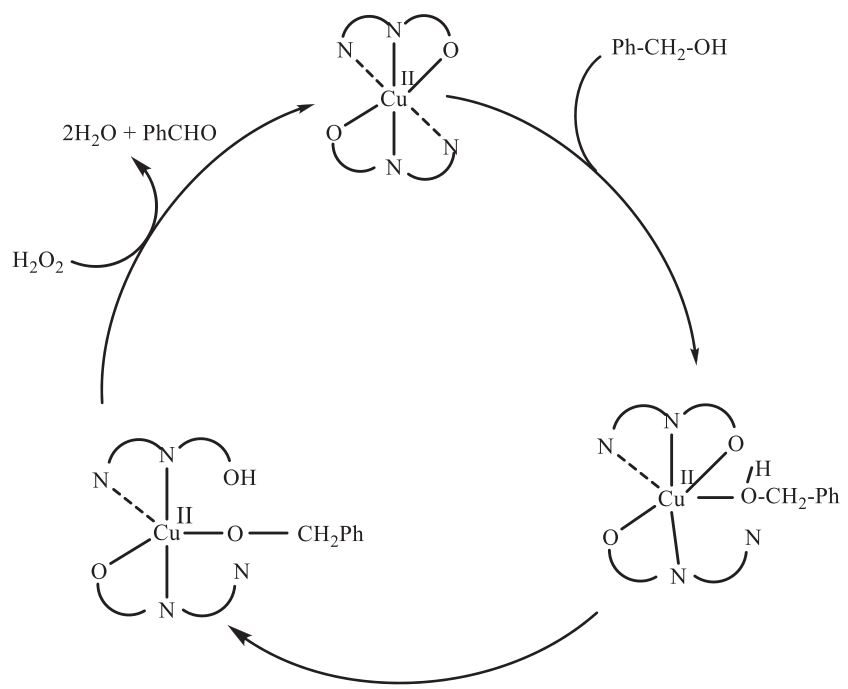

Scheme 2. Probable mechanism for oxidation of alcohols to carbonyl compounds.

temperature. The isolated yields after one hour of reaction time were $60 \%$ and $80 \%$ using $\left[\left(\mathrm{L}_{\mathrm{a}}^{2}\right)_{2} \mathrm{Cu}\right]$ or $\left[\left(\mathrm{L}_{\mathrm{b}}^{2}\right)_{2} \mathrm{Cu}\right]$ catalyst, respectively. A plausible pathway of catalytic process is shown in scheme 2 .

\subsection{Photoluminescence properties and cyanide recognition}

The ligands $\mathrm{HL}_{\mathrm{a}}^{2}$ and $\mathrm{HL}_{\mathrm{b}}{ }^{2}$ exhibited photoluminescence near 505 and $585 \mathrm{~nm}$ on excitation at $300 \mathrm{~nm}$ (figure 3 ). These emissions are attributed to the keto form of the ligands. ${ }^{50,53}$

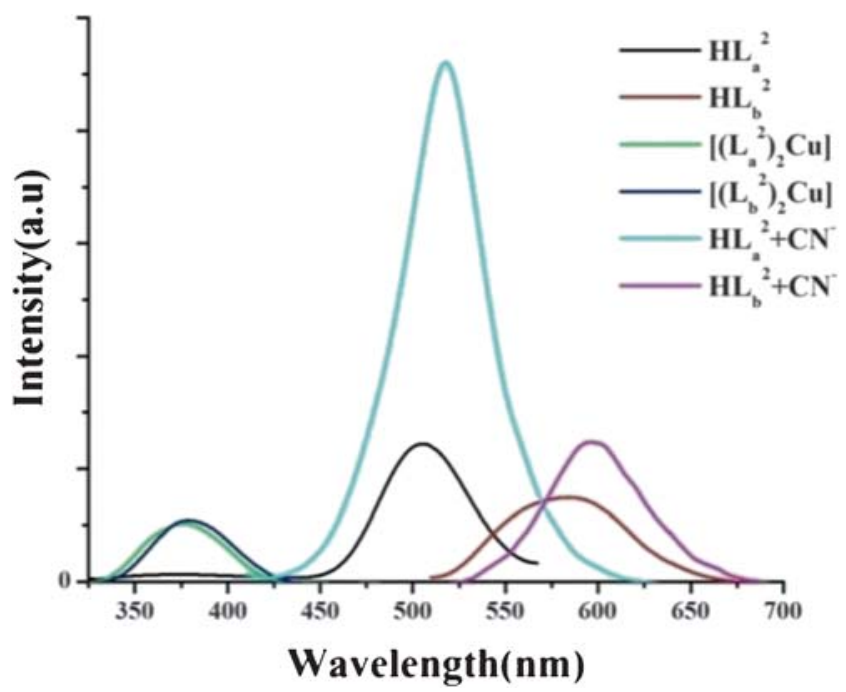

Figure 3. Emission spectra of $\mathrm{HL}_{\mathrm{a}}^{2}\left(\mathrm{c}=1 \times 10^{-5} \mathrm{M}\right)(-)$, $\mathrm{HL}_{\mathrm{b}}^{2}\left(\mathrm{c}=1 \times 10^{-5} \mathrm{M}\right)(-),\left[\left(\mathrm{L}_{\mathrm{a}}^{2}\right)_{2} \mathrm{Cu}\right]\left(\mathrm{c}=2.6 \times 10^{-5}\right.$ M) $(-),\left[\left(\mathrm{L}_{\mathrm{b}}^{2}\right)_{2} \mathrm{Cu}\right]\left(\mathrm{c}=3.9 \times 10^{-5} \mathrm{M}\right)(-),\left[\mathrm{HL}_{\mathrm{a}}^{2}+\mathrm{CN}^{-}\right]$ $\left(\mathrm{c}=1.4 \times 10^{-3} \mathrm{M}\right)(-)$ and $\left[\mathrm{HL}_{\mathrm{b}}{ }^{2}+\mathrm{CN}^{-}\right]\left(\mathrm{c}=1.4 \times 10^{-3} \mathrm{M}\right)$ (-) in $\mathrm{CH}_{3} \mathrm{CN}$ containing $0.2 \%$ DMSO.
On the other hand, the $\left[\left(\mathrm{L}_{\mathrm{a}}^{2}\right)_{2} \mathrm{Cu}\right]$ and $\left[\left(\mathrm{L}_{\mathrm{b}}^{2}\right)_{2} \mathrm{Cu}\right]$ complexes displayed emissions of lower intensity than the ligands (figure 3). The emission behavior of $\left[\left(\mathrm{L}_{\mathrm{a}}^{2}\right)_{2} \mathrm{Cu}\right]$ and $\left[\left(\mathrm{L}_{\mathrm{b}}^{2}\right)_{2} \mathrm{Cu}\right]$ were measured upon addition of several anions and the results are shown in figures 4 and 5 (spectral changes are given in figures S13 and S14 in Supplementary Information). Significant increase of emission intensity on addition of Tetra butyl ammonium cyanide (TABCN), the source of $\mathrm{CN}^{-}$, prompted us to realize the selectivity for cyanide ion. Augmentation of emission intensities of free $\mathrm{HL}_{\mathrm{a}}^{2}$ and $\mathrm{HL}_{\mathrm{b}}^{2}$ ligands were also noticed upon addition of cyanide ions as shown in figure 3.

The changes in emission spectra of $\left[\left(\mathrm{L}_{\mathrm{a}}^{2}\right)_{2} \mathrm{Cu}\right]$ and $\left[\left(\mathrm{L}_{\mathrm{b}}^{2}\right)_{2} \mathrm{Cu}\right]$ were recorded by increasing the cyanide concentration gradually (figures 6 and 7).

No significant peak shifts $\left(375 \mathrm{~nm}\right.$ for $\left[\left(\mathrm{L}_{\mathrm{a}}^{2}\right)_{2} \mathrm{Cu}\right]$ and $375 \mathrm{~nm}$ for $\left.\left[\left(\mathrm{L}_{\mathrm{b}}^{2}\right)_{2} \mathrm{Cu}\right]\right)$ occurred whereas the intensities increased considerably. The emission intensities of $\mathrm{HL}_{\mathrm{a}}{ }^{2}$ and $\mathrm{HL}_{\mathrm{b}}{ }^{2}$ increased upon addition of cyanide ion near 510 and $590 \mathrm{~nm}$ respectively. ${ }^{53}$ Since the emission peak of $\left[\left(\mathrm{L}_{\mathrm{a}}^{2}\right)_{2} \mathrm{Cu}\right]$ did not shift to $505 \mathrm{~nm}$ for $\left(\mathrm{HL}_{\mathrm{a}}^{2}\right)$ or $510 \mathrm{~nm}$ for $\left(\mathrm{HL}_{\mathrm{a}}^{2}+\mathrm{CN}^{-}\right)$upon addition of cyanide,

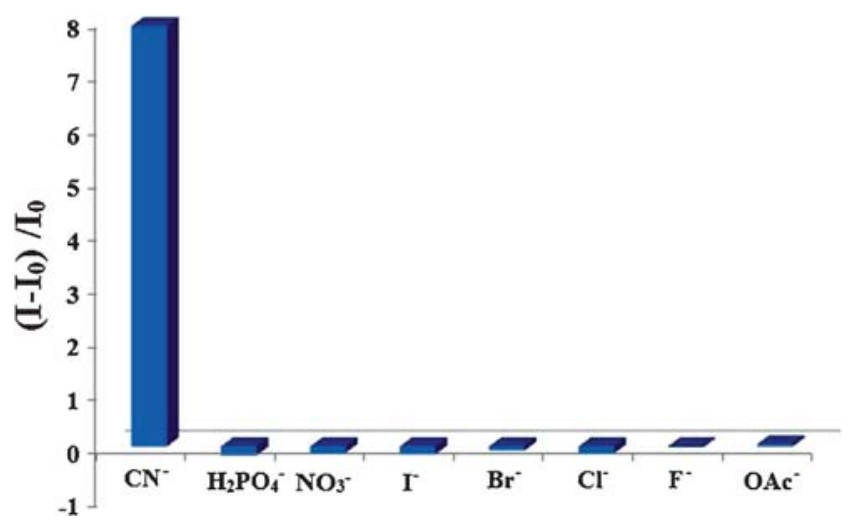

Figure 4. The $\left[\left(\mathrm{I}-\mathrm{I}_{0}\right) / \mathrm{I}_{0}\right]$ values for $\left[\left(\mathrm{L}_{\mathrm{a}}^{2}\right)_{2} \mathrm{Cu}\right]$ at $370 \mathrm{~nm}$ upon addition of 4 equivalent amount of respective anions in $\mathrm{CH}_{3} \mathrm{CN}$ containing $0.2 \%$ DMSO.

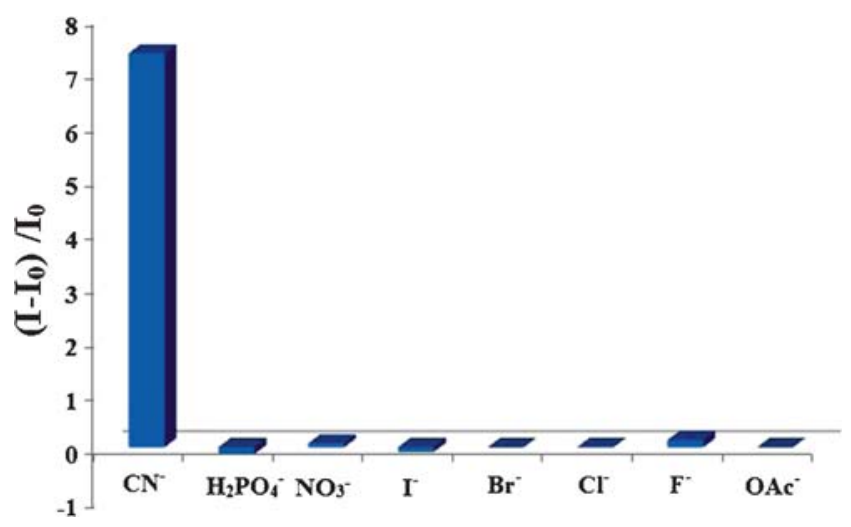

Figure 5. The $\left[\left(\mathrm{I}-\mathrm{I}_{0}\right) / \mathrm{I}_{0}\right]$ values of $\left[\left(\mathrm{L}_{\mathrm{b}}^{2}\right)_{2} \mathrm{Cu}\right]$ at $380 \mathrm{~nm}$ upon addition of 4 equivalent amount of respective anions in $\mathrm{CH}_{3} \mathrm{CN}$ containing $0.2 \%$ DMSO. 


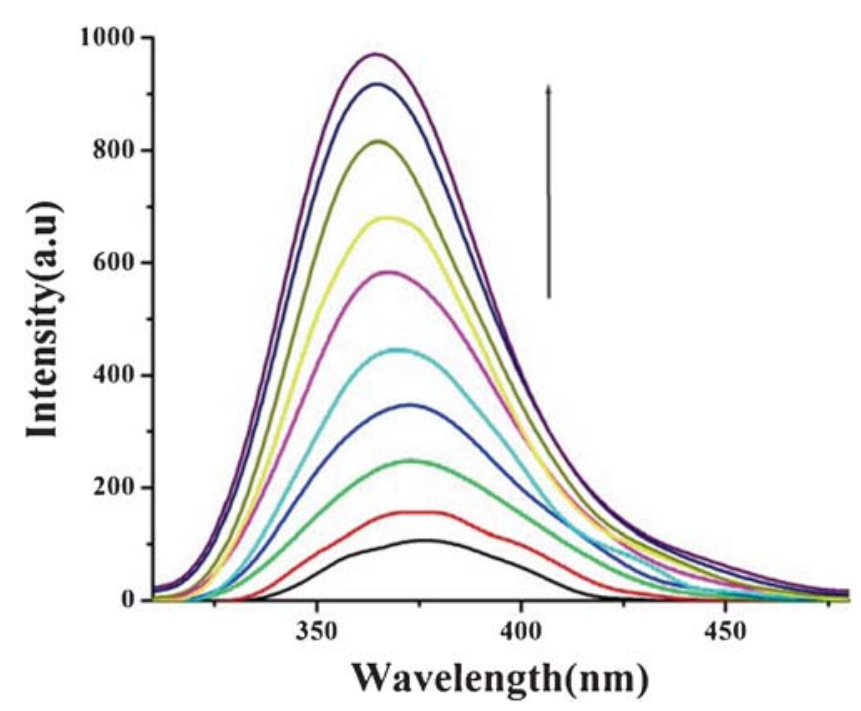

Figure 6. Increment of emission intensity of $\left[\left(\mathrm{L}_{\mathrm{a}}^{2}\right)_{2} \mathrm{Cu}\right]$ solution in $\mathrm{CH}_{3} \mathrm{CN}$ containing $0.2 \%$ DMSO mixed solvent upon gradual addition of TBACN upto 4 equivalent amount.

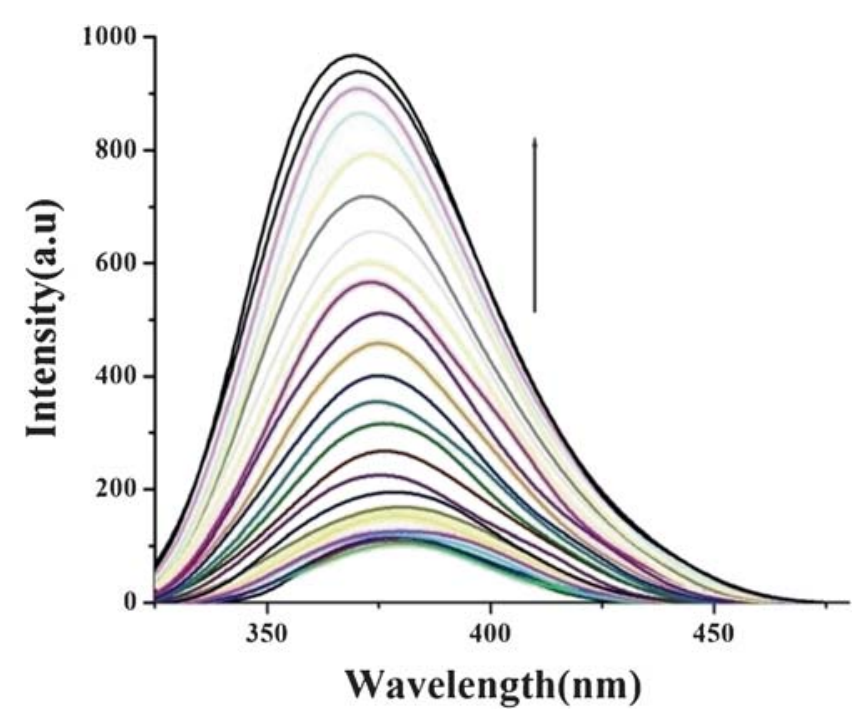

Figure 7. Increment of emission intensity of $\left[\left(\mathrm{L}_{\mathrm{b}}^{2}\right)_{2} \mathrm{Cu}\right]$ upon gradual addition of 4 equiv. amounts of TBACN in $\mathrm{CH}_{3} \mathrm{CN}$ containing $0.2 \%$ DMSO. therefore it was assumed that the ligand dissociation did not take place upon addition of cyanide rather it was due to the cyanation at the free aledyhyde substituent of $\left[\left(\mathrm{L}_{\mathrm{a}}^{2}\right)_{2} \mathrm{Cu}\right] .{ }^{53}$ Similarly, it was speculated that the enhancement of emission intensity of $\left[\left(\mathrm{L}_{\mathrm{b}}^{2}\right)_{2} \mathrm{Cu}\right]$ upon addition of TBACN was a consequence of cyanation at olefinic carbon (C22 of figure $2 \mathrm{~b}$; see above).$^{53}$ The sensitivity toward selective cyanide recognition were $2.6 \times 10^{-5} \mathrm{M}$ for $\left[\left(\mathrm{L}_{\mathrm{a}}^{2}\right)_{2} \mathrm{Cu}\right]$ and $3.9 \times 10^{-5} \mathrm{M}$ for $\left[\left(\mathrm{L}_{\mathrm{b}}^{2}\right)_{2} \mathrm{Cu}\right.$ ] (figures $\mathrm{S} 15$ and $\left.\mathrm{S} 16\right)$. Previously reported $\mathrm{Ni}(\mathrm{II})$ complexes exhibited better sensitivity toward cyanide recognition. ${ }^{53}$ Since the demetallation did not occur for $\left[\left(\mathrm{L}_{\mathrm{a}}^{2}\right)_{2} \mathrm{Cu}\right]$ and $\left[\left(\mathrm{L}_{\mathrm{b}}^{2}\right)_{2} \mathrm{Cu}\right]$ upon addition of cyanide ions, therefore our proposal of cyanation on the nucleophilic carbon at the ligand backbone has been further supported.

\subsection{Antibacterial activity}

The activity results of the metal complex $\left[\left(\mathrm{L}_{\mathrm{b}}^{2}\right)_{2} \mathrm{Cu}\right]$ with control are shown in table 4 and compared with the results of standard antibiotic chloramphenicol. The results indicated that the synthesized metal complex is more effective in case of gram negative bacteria than the gram positive bacteria. The metal complex showed highest inhibition zone $(26 \mathrm{~mm})$ on gram negative bacteria Pseudomonas aeruginosa.

The Minimum Inhibitory Concentrations (MIC) of the metal complexes and chloramphenicol against two gram positive and three gram negative bacteria are presented in table 5. The results of the antibacterial screening indicate that both the compounds exhibit broad spectrum antibacterial activity against all the chosen reference bacteria. These results indicate that the $\left[\left(\mathrm{L}_{\mathrm{b}}^{2}\right)_{2} \mathrm{Cu}\right]$ complex was more sensitive against gram negative bacteria than gram positive bacteria. The chloramphenicol shows lowest MIC $\left(3.9 \mu \mathrm{g} \mathrm{mL}^{-1}\right)$ on gram positive bacteria $B$. Subtilis, whereas, the

Table 4. Screening of antibacterial activity against the metal complex and chloramphenicol.

\begin{tabular}{|c|c|c|c|}
\hline \multirow[b]{2}{*}{ Microorganisms } & \multicolumn{3}{|c|}{ Inhibition zone in diameter $(\mathrm{mm})$ around the discs } \\
\hline & $\begin{array}{l}\text { Metal complex } \\
(60 \mu \mathrm{g} / \mathrm{disc})\end{array}$ & $\begin{array}{l}\text { Chloramphenicol } \\
\text { (10 } \mu \mathrm{g} / \text { disc })\end{array}$ & $\begin{array}{c}\text { Control } \\
\text { (100\% DMSO) }\end{array}$ \\
\hline Bacillus subtilis (MTCC 441) & 18 & 26 & - \\
\hline $\begin{array}{l}\text { Staphylococcus aureus } \\
\text { (MTCC 2522) }\end{array}$ & 15 & 13 & - \\
\hline $\begin{array}{l}\text { Pseudomonas aeruginosa } \\
\text { (MTCC 741) }\end{array}$ & 26 & 13 & - \\
\hline $\begin{array}{l}\text { Shigella dysenteriae } \\
\text { (Clinical isolate) }\end{array}$ & 23 & 18 & - \\
\hline Escherichia coli (MTCC 443) & 19 & 24 & - \\
\hline
\end{tabular}


Table 5. Antibacterial activity of metal complex and reference drug, evaluated by their MIC.

\begin{tabular}{|c|c|c|c|}
\hline \multirow[b]{2}{*}{ Microorganisms } & \multicolumn{3}{|c|}{ Minimum inhibitory concentration $\left(\mu \mathrm{g} \mathrm{mL} L^{-1}\right)$} \\
\hline & Metal complex & Chloramphenicol & $\begin{array}{c}\text { Control } \\
\text { (100\% DMSO) }\end{array}$ \\
\hline Bacillus subtilis (MTCC 441) & 31.2 & 3.9 & - \\
\hline $\begin{array}{l}\text { Staphylococcus aureus } \\
\text { (MTCC 2522) }\end{array}$ & 31.2 & 7.8 & - \\
\hline $\begin{array}{l}\text { Pseudomonas aeruginosa } \\
\text { (MTCC 741) }\end{array}$ & 7.8 & 15.6 & - \\
\hline $\begin{array}{l}\text { Shigella dysenteriae } \\
\text { (Clinical isolate) }\end{array}$ & 15.6 & 15.6 & - \\
\hline Escherichia coli (MTCC 443) & 15.6 & 7.8 & - \\
\hline
\end{tabular}

$\left[\left(\mathrm{L}_{\mathrm{b}}^{2}\right)_{2} \mathrm{Cu}\right]$ complex shows lowest MIC $\left(7.8 \mu \mathrm{g} \mathrm{mL} \mathrm{m}^{-1}\right)$ on gram negative bacteria $P$. aeruginosa which is much less than the MIC $\left(15.6 \mu \mathrm{g} \mathrm{mL}^{-1}\right)$ of chloramphenicol.

\section{Conclusions}

Two kinds of $\mathrm{Cu}$ (II) complexes have been synthesized and structurally characterized. The copper(II) centers possess tetragonally distorted octahedral geometry with two axially elongated bonds. The new copper complexes not only exhibited benzyl alcohol oxidase activity but also good selectivity as cyanide sensors. The recognition of cyanide was monitored by measuring the change in photoluminescence behaviour. Antimicrobial activity of the complexes displayed better sensitivity toward gram negative bacteria.

\section{Supplementary Information (SI)}

CCDC1409893 and CCDC1409894 for $\left[\left(\mathrm{L}_{\mathrm{a}}^{1}\right)_{2} \mathrm{Cu}\right]$ and $\left[\left(\mathrm{L}_{\mathrm{b}}^{2}\right)_{2} \mathrm{Cu}\right]$ contain the supplementary crystallographic data, respectively. These data can be obtained free of charge via http://www.ccdc.cam.ac.uk/conts/retrieving. html, or from the Cambridge Crystallographic Data Centre, 12 Union Road, Cambridge CB2 1EZ, UK; fax: +44 1223336 033; or e-mail: deposit@ccdc.cam.ac.uk.

Figures S1-S6: UV-Vis spectra of $\left[\left(\mathrm{L}_{\mathrm{a}}\right)_{2} \mathrm{Cu}\right]$ and $\left[\left(\mathrm{L}_{\mathrm{b}}\right)_{2} \mathrm{Cu}\right]$, Figures S7-S12: IR spectra of $\left[\left(\mathrm{L}_{\mathrm{a}}\right)_{2} \mathrm{Cu}\right]$ and $\left[\left(\mathrm{L}_{\mathrm{b}}\right)_{2} \mathrm{Cu}\right]$, Figures S13 and S14: Emission spectra of $\left[\left(\mathrm{L}_{\mathrm{a}}\right)_{2} \mathrm{Cu}\right]$ and $\left[\left(\mathrm{L}_{\mathrm{b}}\right)_{2} \mathrm{Cu}\right]$, Figure S15: Detection limits of $\left[\left(\mathrm{L}_{\mathrm{a}}^{2}\right)_{2} \mathrm{Cu}\right]\left(\mathrm{c}=7.30 \times 10^{-6} \mathrm{M}\right)$ at $370 \mathrm{~nm}$ for TBACN $\left(1.4 \times 10^{-3} \mathrm{M}\right)$ in $\mathrm{CH}_{3} \mathrm{CN}$ containing $0.2 \%$ DMSO. Figure S16: Detection limits of $\left[\left(\mathrm{L}_{\mathrm{b}}^{2}\right)_{2} \mathrm{Cu}\right](\mathrm{c}$ $\left.=4.59 \times 10^{-5} \mathrm{M}\right)$ at $380 \mathrm{~nm}$ for TBACN $\left(1.4 \times 10^{-3} \mathrm{M}\right)$ in $\mathrm{CH}_{3} \mathrm{CN}$ containing $0.2 \%$ DMSO. Are given in Supplementary Information. Supplementary data associated with this article can be found, in the online version, at www.ias.ac.in/chemsci.

\section{Acknowledgments}

S.P.P. thanks the CSIR (New Delhi) for research fellowship (09/106(0112)2009-EMR-I). P.P. is thankful to the DST (New Delhi) for funding under DST-WOS-A scheme (No. SR/WOS-A/CS-140/2011). The necessary laboratory and infrastructural facility are provided by the Department of Chemistry, University of Kalyani. The support of DST under FIST and PURSE program and UGC-SAP to the Department of Chemistry, University of Kalyani are acknowledged.

\section{References}

1. Pattanayak P, Parua S P, Patra D, Pratihar J L, Brandão P, Felix V and Chattopadhyay S 2014 Polyhedron 701

2. Pattanayak P, Pratihar J L, Patra D, Lin C-H and Chattopadhyay S 2013 Polyhedron 63133

3. Pattanayak P, Parua S P, Patra D, Pratihar J L, Brandão P, Felix V and Chattopadhyay S 2014 Polyhedron 7943

4. Pattanayak P, Patra D, Pratihar J L, Burrows A, Mahon M F and Chattopadhyay S 2010 Inorg. Chim. Acta 363 2865

5. Joy S, Kramer T, Paul N D, Banerjee P, McGrady J E and Goswami S 2011 Inorg. Chem. 509993

6. Chatterjee I, Saha Chowdhury N, Ghosh P and Goswami S 2015 Inorg. Chem. 545257

7. Mitra K, Patil S, Kondaiah P and Chakravarty A R 2015 Inorg. Chem. 54253

8. Mathur T, Ray U S, Liou J C, Wu J S, Lu T H and Sinha C 2005 Polyhedron 24739

9. Sengupta D, Ghosh P, Chatterjee T, Datta H, Paul N D and Goswami S 2014 Inorg. Chem. 5312002

10. Ghosh P, Samanta S, Roy S K, Joy S, Krämer T, McGrady J E and Goswami S 2013 Inorg. Chem. 52 14040

11. Dutta P, Mondal S, Roy S, Lopez-Torres E and Sinha C 2015 Polyhedron 89203

12. Pramanik A, Basu A and Das G 2010 Polyhedron 29 1980

13. Paul N D, Samanta S, Mondal T K and Goswami S 2011 Inorg. Chem. $\mathbf{5 0} 7886$ 
14. Panja A, Matsuo T, Nagao S and Hirota 2011 Inorg. Chem. 5011437

15. Acharya S, Kejriwal A, Biswas A N, Das P, Neogi D N and Bandyopadhyay P 2012 Polyhedron 3850

16. Das A, Scherer T M, Dutta Chowdhury A, Mobin S M, Kaim W and Lahiri G K 2012 Inorg. Chem. 511675

17. Rajput A, Sharma A K, Barman S K, Koley D, Steinert $\mathrm{M}$ and Mukherjee R 2014 Inorg. Chem. 5336

18. Aritake Y, Takanashi T, Yamazaki A and Akitsu T 2011 Polyhedron 30886

19. Pramanik A and Das G 2010 Polyhedron 292999

20. Prakash G, Nirmala M, Ramachandran R, Viswanathamurthi P, Malecki J G and Sanmartin J 2015 Polyhedron $\mathbf{8 9} 62$

21. Jayakumar K, Sithambaresan M, Aravindakshan A A and Kurup M R P 2014 Polyhedron 7550

22. Fox J P, Ramdhanie B, Zareba A A, Czernuszewicz R S and Goldberg D P 2004 Inorg. Chem. 436600

23. Ruiz R, Surville-Barland C, Aukauloo A, Anxolabehere-Mallart E, Journaux Y, Cano J and Carmen Muñoz M 1997 J. Chem. Soc. Dalton Trans. 745

24. Huffman L M and Stahl S S 2008 J. Am. Chem. Soc. 130 9196

25. Balamurugan R and Palaniandavar M 2001 Inorg. Chem. 402246

26. Colombo A, Dragonetti C, Magni M, Roberto D, Demartin F, Caramori S and Bignozzi C A 2014 ACS Appl. Mater. Interfaces 613945

27. Almeida J do C, Paixão D A, Marzano I M, Ellena J, Pivatto M, Lopes N, Ferreira A M D C, Pereira-Maia E C, Guilardi S and Guerra W 2015 Polyhedron 891

28. Cervera B, Sanz J L, Ibáñez M J, Vila G, LLoret F, Julve M, Ruiz R, Ottenwaelder X, Aukauloo A, Poussereau S, Journaux Y and Carmen Muñoz M 1998 J. Chem. Soc. Dalton Trans. 781

29. Zink D M, Volz D, Baumann T, Mydlak M, Flügge H, Friedrichs J, Nieger M and Bräse S 2013 Chem. Mater. 254471

30. Schatz M, Becker M, Thaler F, Hampel F, Schindler S, Jacobson R R, Tyeklár Z, Murthy N N, Ghosh P, Chen Q, Zubieta J and Karlin K D 2001 Inorg. Chem. 402312

31. Mirza A H, Ali M A, Bernhardt P V and Asri I 2014 Polyhedron 81723

32. Hannigan S F, Lum J S, Bacon J W, Moore C, Golen J A, Rheingold A L and Doerrer L H 2013 Organometallics 323429

33. Meghdadi S, Amirnasr M, Mirhashemi A and Amiri A 2015 Polyhedron 97234

34. Choubey S, Roy S, Chattopadhayay S, Bhar K, Ribas J, Monfort M and Ghosh B K 2015 Polyhedron 8939

35. Pawlicki M, Kańska I and Latos-Grazyński L 2007 Inorg. Chem. 466575

36. Cargnelutti R, Hagenbach A, Abram U, Burrow R A and Schulz Lang E 2015 Polyhedron 9633

37. Colombo A, Dragonetti C, Roberto D, Valore A, Biagini P and Melchiorre F 2013 Inorg. Chim. Acta 407204

38. Golchoubian H, Moayyedi G, Rezaee E and Bruno G 2015 Polyhedron 9671

39. Dinda J, Ray U, Mostafa G, Lu T-H, Usman A, Razak I A, Chantrapromma S, Fun H-K and Sinha C 2003 Polyhedron 22247
40. Aritake Y, Takanashi T, Yamazaki A and Akitsu T 2011 Polyhedron 30886

41. Colacio E, Dominguez-Vera J M, Kivekas R, Moreno J M and Ruiz J 1994 Inorg. Chim. Acta 219127

42. Rezvani Z, Divband B, Abbasi A R and Nejati K 2006 Polyhedron 251915

43. Das S, Banerjee P, Peng S -M, Lee G -H, Kim J and Goswami S 2006 Inorg. Chem. 45562

44. Khandar A A and Nejati K 2000 Polyhedron 19607

45. Datta D and Chakravorty A 1983 Inorg. Chem. 221085

46. Pratt R C, Lyons C T, Wasinger E C and Stack T D P 2012 J. Am. Chem. Soc. 1347367

47. Shimazaki Y, Huth S, Hirota S and Yamauchi O 2002 Inorg. Chim. Acta. 331168

48. Kruse T, Weyhermuller T and Wieghardt K 2002 Inorg. Chim. Acta. 33181

49. Taki M, Hattori H, Osako T, Nagatomo S, Shiro, Kitagawa, M T and Itoh S 2004 Inorg. Chim. Acta. 357 3369

50. Vaidyanathan M, Viswanathan R, Palaniandavar M, Balasubramanian, T, Prabhaharan P and Muthiah P 1998 Inorg. Chem. 376418

51. Saint-Aman E, Menage S, Pierre J L, Defrancq E and Gellon G 1998 New. J. Chem. 22393

52. Wang Y, DuBois J L, Hedman B, Hodgson K O and Stack T D P 1998 Science 279537

53. Parua S P, Mondal P, Pattanayak P and Chattopadhyay S 2015 Polyhedron 89142

54. Halfen J A, Jazdzewski B A, Mahapatra S, Berreau L, Wilkinson M E C, Que L Jr. and Tolman W B 1997 J. Am. Chem. Soc. 1198217

55. Whittaker J W 2003 Chem. Rev. 1032347

56. Gamez P, Koval I A and Reedijk J 2004 Dalton Trans. 4079

57. Munoz-Munoz J L, Garcia-Molina F, Garcia-Ruiz A P, Molina-Alarcon M, Tudela J, Garcia-Canovas F N and Rodriguez-Lopez J 2008 Biochem. 416431

58. Pierre J-L 2000 Chem. Soc. Rev. 2925

59. Whittaker M M, Ballou D P and Whittaker J W 1998 Biochemistry 378426

60. Perrin D D and Armarego W L F 1988 In Purification of Laboratory Chemicals $3^{\text {rd }}$ ed. (New York: Pergamon)

61. (a) Maiti N, Pal S and Chattopadhyay S 2001 Inorg. Chem. 40 2204; (b) Maiti N, Dirghangi B K and Chattopadhyay S 2003 Polyhedron 223109

62. Sheldrick G M 2008 Acta Crystallogr., Sect. A: Found. Crystallogr. 64112

63. Sheldrick G M 1997 SHELEXL-97 program for the refinement of the crystals structures from diffraction data (University of Gottingen: Gottingen, Germany)

64. Murray P R, Baron E J, Pfaller M A, Tenover F C and Yolke R H 1995 In Manual of Clinical Microbiology $6^{\text {th }}$ ed. (Washington, DC: ASM)

65. Sokmen A, Gulluce M, Askin Akpulat H, Daferera D, Tepe B, Polissiou M, Sokmen M and Sahin F 2004 Food Control 15627

66. Swamya G Y S K, Ravikumar K and Ramakrishna K V S 2013 Polyhedron 49145

67. Lorinc Š, Švorec J, Melnik M and Koman M 2008 Polyhedron 273545 
68. Kozlevc B, Golobic A and Strauch P 2006 Polyhedron 252824

69. Banerjee S, Adhikary C, Rizzoli C and Pal R 2014 Inorg. Chim. Acta. 409202

70. Li X, Fang C, Zong Z, Cui L, Bi C and Fan Y 2015 Inorg. Chim. Acta. 432198

71. Itoh S, Takayama S, Arakawa R, Furuta A, Komatsu M, Ishida A, Takamuku S and Fukuzumi S 1997 Inorg. Chem. 361407

72. Asami K, Takashina A, Kobayashi M, Iwatsuki S, Yajima T, Kochem A, Gastel M, Tani F, Kohzuma,
Thomasg T F and Shimazaki Y 2014 Dalton Trans. 43 2283

73. Antinolo A, Hermosilla F C, Cadierno V, Alvarez J and Otero A 2012 ChemCatChem 4123

74. Singaram B, Rangaishenvi M V and Brown H C $1991 \mathrm{~J}$. Org. Chem. 561543

75. Abad A, Almela C, Corma A and Garcia H 2006 Tetrahedron 626666

76. Fernandesa R R, Lasri J, Guedes da Silva M F C, Silva J A L, Silva F J J R and Pombeiro A J L $2011 \mathrm{~J}$. Mol. Catal. A: Chem. 35110 